\title{
Use of Clozapine in the Treatment-Resistant Schizoprenia
}

\author{
Oğuzhan Kütük (i)
}

\section{SCHIZOPHRENIA}

Schizophrenia is a mental disorder that has been the most challenging problem in medicine since the last century, but even today, its various aspects have not been fully explained. It is a severe mental illness that starts at young age, where people are withdrawn from their interpersonal relationships and realities, and severe problems are observed in their thoughts, feelings and behaviors. ${ }^{[1]}$ Schizophrenia is seen in $1 \%$ of all populations. ${ }^{[2]}$ The etiologic process or processes that make up the physiopathology of schizophrenia are not fully known. ${ }^{[3]}$

In clinical practice, schizophrenia is diagnosed according to diagnostic and statistical manual of mental disorders (DSM-V). According to these diagnostic criteria; positive symptoms over a significant period of one month; delusions, hallucinations, unreasonable speech, catatonic behavior and negative symptoms; two or more symptoms, such as social withdrawal or lack of motivation. For a significant part of the time since the onset of this disorder, the level of functionality has deteriorated in one or more major areas, such as work, interpersonal relationships, or self-care. Symptoms last for at least six months. ${ }^{[4]}$

Department of Psychology, Bingöl University, Bingöl, Turkey

Correspondence: Oğuzhan Kütük. Bingöl Üniversitesi, Psikoloji Bölümü, 12000, Bingöl, Türkiye.

E-mail: kutukoguzhan96@gmail.com

Cite this article as: Kütük $O$. Use of Clozapine in the Treatment-Resistant Schizoprenia. JEB Med Sci 2020;1(1):36-41.

doi: 10.5606/jebms.2020.75609

Received : July 24, 2019

Accepted : October 25, 2020

Published online : April 23, 2020

(O2020 Journal of Experimental and Basic Medical Sciences. All rights reserved.

\begin{abstract}
Clozapine is one of the new antipsychotic drugs. After its emergence, it has been widely used in schizophrenia patients. The mechanism of action of clozapine has made it a gold standard, particularly in the treatment of resistant schizophrenia. This is achieved by its effect on many receptors in the brain, unlike other atypical antipsychotics. Furthermore, the fact that clozapine reduces suicide attempts in schizophrenics has made it more important than other antipsychotics.

Keywords: $5 \mathrm{HT}-2 \mathrm{~A}$ antagonism, clozapine, D2 receptor, first and second generation antipsychotics; schizophrenia.
\end{abstract}

In the treatment of these patients; First generation antipsychotics or second generation antipsychotics are commonly used (Table 1). In some cases, these two groups of drugs are used together. In addition to antipsychotic drugs, additional treatment methods such as lithium, anticonvulsants, beta blockers, antidepressants, benzodiazepines, glycine and electroconvulsive therapy are also used. ${ }^{[5]}$

Second-generation antipsychotics produce less extrapyramidal side effects (such as muscle

$\begin{array}{ll}\begin{array}{l}\text { Table 1. A detailed list of first and second generation } \\ \text { antipsychotics }{ }^{[j]}\end{array} & \text { Monotherapy } \\ \text { Chlarpromazine } & \text { Aripiprazole } \\ \text { Droperidol } & \text { Asenapine } \\ \text { Fluphenazine } & \text { Clozapine } \\ \text { Haloperidol } & \text { lloperidone } \\ \text { Loxapine } & \text { Lurasidone } \\ \text { Perphenazine } & \text { Olanzapine } \\ \text { Pimozide } & \text { Paliperidone } \\ \text { Prochlorperazine } & \text { Quetiapine } \\ \text { Thioridazine } & \text { Risperidone } \\ \text { Thiothixene } & \text { Ziprasidone } \\ \text { Trifluoperazine } & \end{array}$


contraction, tremor, shaking) than the first-generation drugs at the recommended antipsychotic doses. ${ }^{[6]}$

\section{THE CONCEPT OF RESISTANCE TO TREATMENT IN SCHIZOPHRENIA}

Despite the developments in recent years, problems are still experienced in the treatment of this disease. A high proportion of patients (30-50\%) have resistance to treatment. ${ }^{[7]}$ Almost $70 \%$ of patients with schizophrenia who are considered to have adequate response to antipsychotic treatment with positive symptoms such as delusion, hallucination, and unreasonable behavior still suffer clinically significant negative symptoms and decrease in cognitive activity ${ }^{[4]}$ The most common definition of treatment-resistant schizophrenia is; "At least two antipsychotic drugs, provided that one of them is a second generation antipsychotic, provided that the appropriate dose for at least 6-8 weeks, despite the clinical development can't be achieved". ${ }^{[8]}$ The age of onset of treatment-resistant schizophrenics is lower, the frequency of male patients is higher, the onset of symptoms is slower and less noisy, negative symptoms are more frequent, general symptom severity is higher, lateral and third ventricles are wider, basal growth hormone levels are higher. ${ }^{[9-11]}$ Findings such as cortical shrinkage and lower catecholamine levels in cerebrospinal fluid have been reported in treatment-resistant patients. ${ }^{[12-14]}$ Szeszko et al. ${ }^{[15]}$ compared the brains that responded to antipsychotic treatment and did not respond (resistant schizophrenia), and found more cortical thinning in the prefrontal and occipital regions of the brains of those who did not respond to treatment. In the same study, brain images of the individuals who responded to the treatment were examined and the right and left inferior temporal gyri thickness were found to be thicker in the patients who responded to the treatment faster (Figure 1).

\section{EMERGENCE OF CLOZAPINE}

Clozapine is a tetracyclic compound synthesized in 1958 (Bern, Switzerland). Clozapine has started to be used in the treatment of psychotic patients in Europe in the 1960s with positive results obtained in clinical trials. However, this drug was largely withdrawn from clinical practice in 1975 because of the development of agranulocytosis in 13 Finnish patients and eight of them died from secondary infections. In the next decade, clozapine use in Europe has been continued in selected cases and it has been reported that the drug has superior clinical effect compared to classical antipsychotic drugs, does not cause extrapyramidal side effects and the risk of agranulocytosis is between $1-2 \% \cdot{ }^{[16]}$ The positive results obtained in 268 chronic and treatment-resistant patients in the USA ${ }^{[17]}$ and the approval of the Food and Drug Administration (FDA) in 1990, its use was adhered to certain rules and became widely used in the world. ${ }^{[16]}$

\section{COMPARISON OF CLOZAPINE WITH OTHER ANTIPSYCHOTICS}

Clozapine is the first of the new generation antipsychotic drugs and is generally accepted as one of the most effective antipsychotic drugs. It was found to be effective in $30-61 \%$ of resistant schizophrenic patients in studies that did not respond to firstgeneration antipsychotics. ${ }^{[18-22]}$ Numerous controlled studies have shown that clozapine is superior to haloperidol and chlorpromazine in soothing positive psychotic symptoms, aggression and negative symptoms in treatment-resistant patients. . $^{[5,23-25]}$

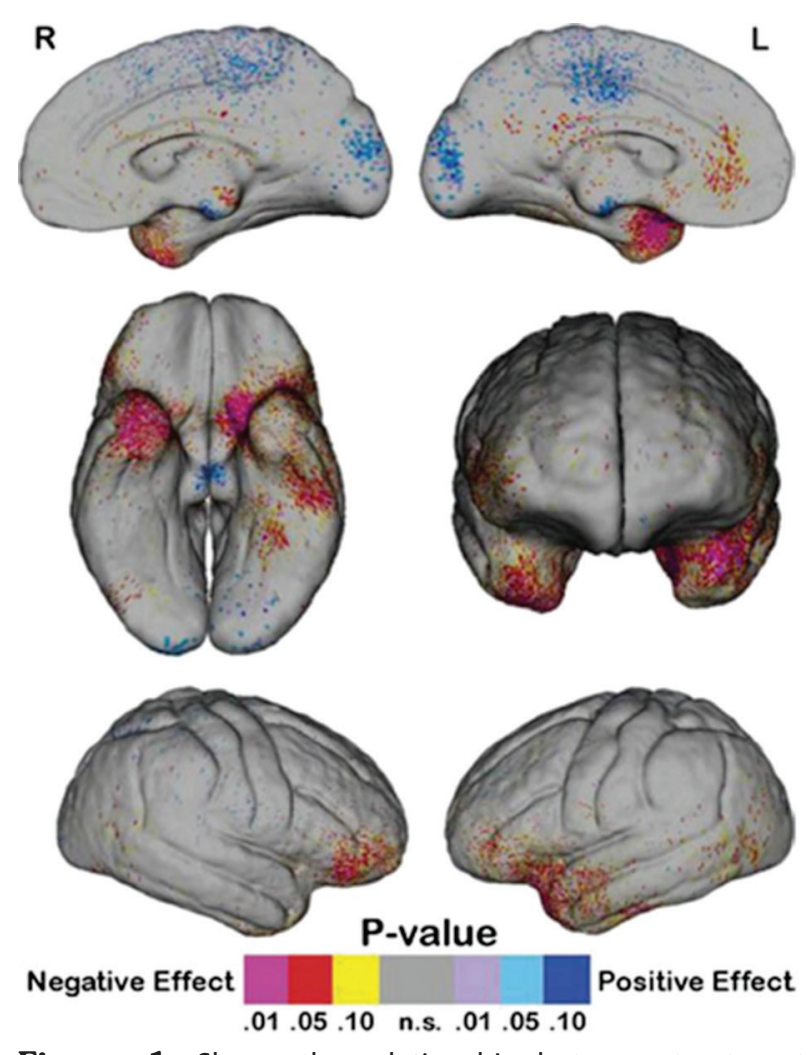

Figure 1. Shows the relationship between treatment response rate and cortical thickness. Warm colors show negative correlations and cold colors show positive correlations. ${ }^{[15]}$ 


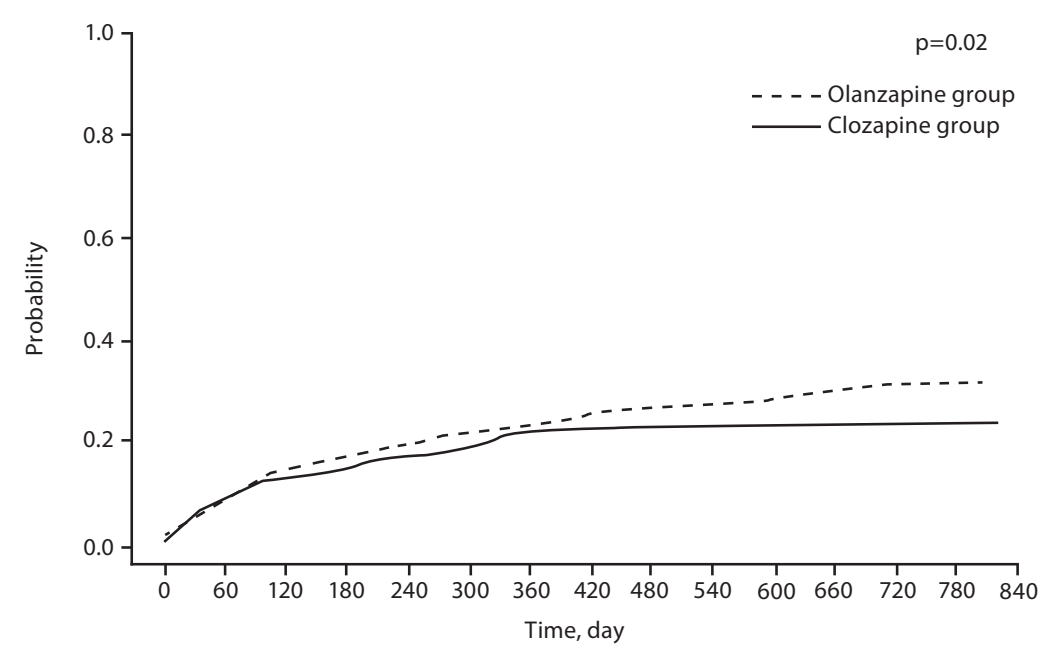

\begin{tabular}{|l|c|c|c|c|c|c|}
\hline Day & 0 & 70 & 182 & 378 & 574 & 742 \\
\hline Clozapine & & & & & & \\
\hline Cumulative events, no & 0 & 43 & 69 & 91 & 100 & 102 \\
\hline At risk, no & 490 & 393 & 346 & 308 & 277 & 35 \\
\hline Olanzapine & & & & & & \\
\hline Cumulative events, no & 0 & 50 & 81 & 112 & 128 & 141 \\
\hline At risk, no & 490 & 410 & 365 & 312 & 269 & 39 \\
\hline
\end{tabular}

Figure 2. Distribution of rates according to suicide attempt before and after clozapine. ${ }^{[31]}$

In most of the studies, clozapine is compared with risperidone and olanzapine, ie. second generation antipsychotics. Some double-blind controlled studies suggest that olanzapine and risperidone have a similar effect with clozapine, particularly in soothing positive symptoms in treatmentresistant schizophrenia, while some controlled studies suggest that clozapine is superior in the treatment of positive and negative symptoms in contrast to olanzapine and risperidone. ${ }^{[25-27]}$ In an important study by McEvoy et al. ${ }^{[28]} 99$ patients who had not responded to treatment were treated with clozapine, olanzapine, risperidone or quetiapine, and patients treated with clozapine improved significantly less positive and negative symptoms than those treated with other atypical antipsychotics (except olanzapine). Based on these studies, clozapine is the first atypical antipsychotic to prove superiority in terms of both clinical efficacy and side effects over classical antipsychotics.

There is insufficient evidence that atypical or typical antipsychotics, antidepressant drugs and with the exception of clozapine, have an effect on fatal or non-fatal suicidal behavior. ${ }^{[29,30]}$ However, Meltzer et al. ${ }^{[31]}$ found that clozapine was an antipsychotic that reduced suicide rates in patients with schizophrenia and supported this finding in many studies. In their study, clozapine treatment was superior to olanzapine treatment in the prevention of suicide attempts in schizophrenia and schizoaffective patients (Figure 2). In addition, according to information obtained from clozapine records in the USA and the United Kingdom, it was found that suicide risk was reduced in clozapine users, and the FDA approved the indication that clozapine reduces suicide risk. ${ }^{[32]}$ In addition, clozapine can reduce the hospitalization of patients by $72 \%{ }^{[33]}$

\section{MECHANISM OF ACTION OF ANTIPSYCHOTIC DRUGS AND CLOZAPINE}

The effects of antipsychotic drugs on the positive symptoms in schizophrenia are known to be due to their D2 receptor blockade in the mesolimbic system, and there is a strong correlation between the mean doses and percentages of binding to D2 receptors. However, in the positron emission tomography studies, no difference was found between the treatment-resistant and non-treatment-resistant 
patients in terms of the D2 receptor occupation of antipsychotic drugs in the striatum. In addition, PET and SPECT studies in this group have shown that psychotic symptoms persist even when complete postsynaptic D2 receptor blockade is provided in these patients. ${ }^{[34,35]}$

Clozapine, which has been shown to be more effective in treatment-resistant patients, has lower D2 receptor blockade capacity than first-generation antipsychotics, but its effects on different receptors are more pronounced. In this case, antipsychotic effect cannot be explained only by postsynaptic D2 receptor blockade. ${ }^{[36,37]}$

The effect of clozapine on negative symptoms in contrast to typical antipsychotics is due to a different mechanism of action. ${ }^{[38,39]}$ In one study, activity against negative symptoms was suggested to be related to serotonin $5 \mathrm{HT}-2 \mathrm{~A}$ antagonist activation. Serotonergic stimulation via serotonin 5HT-2A receptors reduces dopamine and noradrenaline release via dopamine and noradrenaline neurons, whereas 5HT-2A antagonism increases the release of dopamine and noradrenaline by eliminating this indirect reduction. ${ }^{[40]}$ In laboratory studies, it has been shown that dopamine and noradrenaline secretion is increased in the prefrontal cortex of rats given $5 \mathrm{HT}-2 \mathrm{~A}$ antagonists. ${ }^{[4]]}$ With this feature of serotonin $5 \mathrm{HT}-2 \mathrm{~A}$ antagonism, the effect of clozapine on the prefrontal cortex is thought to provide an improvement in negative, cognitive and depressive symptoms. ${ }^{[40]}$

\section{CLOZAPINE SIDE EFFECTS}

Lieberman $^{[42]}$ reported that clozapine side effects were higher in the acute period (first 6 weeks). He reported that during the acute phase, sedation, hypersalivation, constipation, increased appetite, weight gain, hypotension and tachycardia has been developed and decreased during the maintenance period after six weeks. The UK Clozapine Study Group ${ }^{[43]}$ reported that hypersalivation was the most common side effect (54\%), followed by sedation $(46 \%)$, constipation $(44 \%)$, weight gain $(11 \%)$, and epileptic seizures (9\%). The two most important side effects associated with clozapine are agranulocytosis and epilepsy. Agranulocytosis is characterized by a decrease in leukocytes, particularly polymorphic leukocytes, and can occur suddenly or gradually. Research has been said to be seen in $1-2 \%$ of patients treated with clozapine, $0.38 \%$ was observed in clinical applications. ${ }^{[4]]}$ In one study, $75 \%$ of schizophrenia patients receiving clozapine had elektroensefalografi (EEG) abnormalities and 30\% had epileptic activity, and in another study $47.1 \%$ of clozapine-taking psychiatric patients had EEG abnormalities. ${ }^{[45,46]}$ Therefore, second-generation drugs such as risperidone, olanzapine, quetiapine, ziprasidone, and aripiprazole have tried to reduce the negative side effects of clozapine and at the same time mimic the superior efficacy of positive and negative symptoms. ${ }^{[25]}$

Therefore, clozapine is still the gold standard antipsychotic for treatment-resistant schizophrenia patients due to its superior efficacy. ${ }^{[47]}$

\section{Declaration of conflicting interests}

The author declared no conflicts of interest with respect to the authorship and/or publication of this article.

\section{Funding}

The author received no financial support for the research and/or authorship of this article.

\section{REFERENCES}

1. Tandon R, Gaebel W, Barch DM, Bustillo J, Gur RE, Heckers $S$, et al. Definition and description of schizophrenia in the DSM-5. Schizophr Res 2013;150:3-10.

2. Practice guideline for the treatment of patients with schizophrenia. American Psychiatric Association. Am J Psychiatry 1997;154:1-63.

3. Ruiz P. Comprehensive textbook of psychiatry. In: Sadock BJ, Sadock VA, editors. Vol. 1. Philadelphia: Lippincott Williams \& Wilkins; 2000. p. 938-50.

4. Stahl SM. Stahl's essential psychopharmacology: neuroscientific basis and practical applications. 4th ed. Cambridge: Cambridge University Press; 2013.

5. Meltzer HY, Kostakoglu E. Treatment-Resistant Schizophrenia. In: Lieberman JA, Murray R, editors. Comprehensive of Schizophrenia. London: Martin Dunitz Press; 2000. p. 181-203.

6. Leucht S, Corves C, Arbter D, Engel RR, Li C, Davis JM. Second-generation versus first-generation antipsychotic drugs for schizophrenia: a meta-analysis. Lancet 2009;373:31-41.

7. Ryan MC, Thakore JH. Physical consequences of schizophrenia and its treatment: the metabolic syndrome. Life Sci 2002;71:239-57.

8. Meltzer HY. Defining treatment refractoriness in schizophrenia. Schizophr Bull 1990;16:563-5.

9. Loebel AD, Lieberman JA, Alvir JM, Mayerhoff DI, Geisler SH, Szymanski SR. Duration of psychosis and outcome in first-episode schizophrenia. Am J Psychiatry 1992;149:1183-8.

10. Meltzer HY, Rabinowitz J, Lee MA, Cola PA, Ranjan $\mathrm{R}$, Findling $\mathrm{RL}$, et al. Age at onset and gender of schizophrenic patients in relation to neuroleptic resistance. Am J Psychiatry 1997;154:475-82.

11. Pickar D, Owen RR, Litman RE, Konicki E, Gutierrez R, Rapaport MH. Clinical and biologic response to clozapine in patients with schizophrenia. Crossover comparison 
with fluphenazine. Arch Gen Psychiatry 1992;49:345-53.

12. Stern RG, Kahn RS, Davidson M. Predictors of response to neuroleptic treatment in schizophrenia. Psychiatr Clin North Am 1993;16:313-38.

13. Bilder RM, Wu H, Chakos $\mathrm{MH}$, Bogerts B, Pollack S, Aronowitz J, et al. Cerebral morphometry and clozapine treatment in schizophrenia. J Clin Psychiatry 1994;55:53-6.

14. van Kammen DP, Schooler N. Are biochemical markers for treatment-resistant schizophrenia state dependent or traits? Clin Neuropharmacol 1990;13:S16-28.

15. Szeszko PR, Narr KL, Phillips OR, McCormack J, Sevy S, Gunduz-Bruce $\mathrm{H}$, et al. Magnetic resonance imaging predictors of treatment response in first-episode schizophrenia. Schizophr Bull 2012;38:569-78.

16. Van Kammen DP, Marder SR. Clozapine. In: Kaplan HI, Sadock BJ, editors. Comprehensive Textbook of Psychiatry. 6th ed. Baltimore: Williams \& Wilkins; 1995. p. 1979-87.

17. Barnes TR, McEvedy CJ. Pharmacological treatment strategies in the non-responsive schizophrenic patient. Int Clin Psychopharmacol 1996;11:67-71.

18. Essock SM, Hargreaves WA, Covell NH, Goethe J. Clozapine's effectiveness for patients in state hospitals: results from a randomized trial. Psychopharmacol Bull 1996;32:683-97.

19. Lindström LH. The effect of long-term treatment with clozapine in schizophrenia: a retrospective study in 96 patients treated with clozapine for up to 13 years. Acta Psychiatr Scand 1988;77:524-9.

20. Meltzer HY. Clozapine and other atypical neuroleptics: efficacy, side effects, optimal utilization. J Clin Psychiatry 1994;12:38-42.

21. Fitton A, Heel RC. Clozapine. A review of its pharmacological properties, and therapeutic use in schizophrenia. Drugs 1990;40:722-47.

22. Claghorn J, Honigfeld G, Abuzzahab FS Sr, Wang R, Steinbook R, Tuason V, et al. The risks and benefits of clozapine versus chlorpromazine. JClin Psychopharmacol 1987;7:377-84.

23. Volavka J, Czobor P, Nolan K, Sheitman B, Lindenmayer $J P$, Citrome L, et al. Overt aggression and psychotic symptoms in patients with schizophrenia treated with clozapine, olanzapine, risperidone, or haloperidol. J Clin Psychopharmacol 2004;24:225-8.

24. Lindenmayer JP, Czobor P, Volavka J, Lieberman JA, Citrome L, Sheitman B, et al. Effects of atypical antipsychotics on the syndromal profile in treatmentresistant schizophrenia. J Clin Psychiatry 2004;65:551-6.

25. Volavka J, Czobor P, Sheitman B, Lindenmayer JP, Citrome L, McEvoy JP, et al. Clozapine, olanzapine, risperidone, and haloperidol in the treatment of patients with chronic schizophrenia and schizoaffective disorder. Am J Psychiatry 2002;159:255-62.

26. Tollefson GD, Birkett MA, Kiesler GM, Wood AJ; Lilly Resistant Schizophrenia Study Group. Doubleblind comparison of olanzapine versus clozapine in schizophrenic patients clinically eligible for treatment with clozapine. Biol Psychiatry 2001;49:52-63.

27. Klieser E, Lehmann E, Kinzler E, Wurthmann C, Heinrich K. Randomized, double-blind, controlled trial of risperidone versus clozapine in patients with chronic schizophrenia. J Clin Psychopharmacol 1995;15:45S-51S.

28. McEvoy JP, Lieberman JA, Stroup TS, Davis SM, Meltzer HY, Rosenheck RA, et al. Effectiveness of clozapine versus olanzapine, quetiapine, and risperidone in patients with chronic schizophrenia who did not respond to prior atypical antipsychotic treatment. Am J Psychiatry 2006;163:600-10.

29. Siris SG. Suicide and schizophrenia. J Psychopharmacol 2001;15:127-35.

30. Khan A, Khan SR, Leventhal RM, Brown WA. Symptom reduction and suicide risk among patients treated with placebo in antipsychotic clinical trials: an analysis of the food and drug administration database. Am J Psychiatry 2001;158:1449-54.

31. Meltzer HY, Alphs L, Green Al, Altamura AC, Anand R, Bertoldi $A$, et al. Clozapine treatment for suicidality in schizophrenia: International Suicide Prevention Trial (InterSePT). Arch Gen Psychiatry 2003;60:82-91.

32. Pompili M, Amador XF, Girardi P, Harkavy-Friedman J, Harrow M, Kaplan K, et al. Suicide risk in schizophrenia: learning from the past to change the future. Ann Gen Psychiatry 2007;6:10.

33. Meltzer HY. Clozapine pattern of efficacy in treatment resistant schizophrenia. In: Meltzer HY, editor. Novel Antipsychotic Drugs. New York: Raven Press Ltd; 1992. p. 33-46.

34. Meltzer HY. Treatment-resistant schizophrenia--the role of clozapine. Curr Med Res Opin 1997;14:1-20.

35. Wolkin A, Barouche F, Wolf AP. Dopamine blockade and clinical response: evidence for two biological subgroups of schizophrenia. J Clin Psychiatry 1994;55:53-6.

36. Deutch AY.Identification of the neural systems subserving the actions of clozapine: clues from immediate-early gene expression. J Clin Psychiatry 1994;55:37-42.

37. Pickar D, Owen RR Jr, Litman RE, Hsiao JK, Su TP. Predictors of clozapine response in schizophrenia. J Clin Psychiatry 1994;55:129-32.

38. Thompson PA, Meltzer HY. Positive, negative, and disorganisation factors from the Schedule for Affective Disorders and Schizophrenia and the Present State Examination. A three-factor solution. Br J Psychiatry 1993;163:344-51.

39. Meltzer HY. Clinical studies on the mechanism of action of clozapine: the dopamine-serotonin hypothesis of schizophrenia. Psychopharmacology 1989;99:S18-S27.

40. Stahl SM. Symptoms and circuits, part 3: schizophrenia. J Clin Psychiatry 2004;65:8-9.

41. Zhang W, Perry KW, Wong DT, Potts BD, Bao J, Tollefson $G D$, et al. Synergistic effects of olanzapine and other antipsychotic agents in combination with fluoxetine on norepinephrine and dopamine release in rat prefrontal cortex. Neuropsychopharmacology 2000;23:250-62.

42. Lieberman JA, Safferman AZ, Pollack S, Szymanski S, Johns C, Howard A, et al. Clinical effects of clozapine 
in chronic schizophrenia: response to treatment and predictors of outcome. Am J Psychiatry 1994;151:1744-52.

43. The safety and efficacy of clozapine in severe treatmentresistant schizophrenic patients in the UK. Clozapine Study Group. Br J Psychiatry 1993;163:150-4.

44. Miller DD. Review and management of clozapine side effects. J Clin Psychiatry 2000;61:14-7.

45. Montalenti E, Gaia S, Fiori L. Clozapine-induced Seizures and EEG Alterations: follow-up of 60 Patients.
Epilepsia 1997;38(Supll 3):3.

46. Centorrino F, Price BH, Tuttle M, Bahk WM, Hennen J, Albert MJ, et al. EEG abnormalities during treatment with typical and atypical antipsychotics. Am J Psychiatry 2002;159:109-15.

47. Mouaffak F, Tranulis C, Gourevitch R, Poirier MF, Douki $S$, Olié JP, et al. Augmentation strategies of clozapine with antipsychotics in the treatment of ultraresistant schizophrenia. Clin Neuropharmacol 2006;29:28-33. 